\title{
Confucian Values and Entrepreneurial Firm Legitimacy
}

\author{
Kong-Hee Kim \\ Department of Management and Entrepreneurship \\ Herberger Business School, St. Cloud State University \\ St.Cloud State University \\ St.Cloud, MN 56301 \\ Tel: (320) 308-3911Ｅ-mail: kkim@stcloudstate.edu
}

\author{
James A. Tan \\ Department of Management and Entrepreneurship \\ Herberger Business School, St. Cloud State University \\ St. Cloud, MN 56301-4498 \\ Tel: (320) 308-1605Ｅ-mail: jatan@stcloudstate.edu
}

Received: Jan. 9, 2019 Accepted: Feb. 26, $2019 \quad$ Published: April 1, 2019

doi:10.5296/jmr.v11i2.14335 URL: https://doi.org/10.5296/jmr.v11i2.14335

\begin{abstract}
This paper offers a model based on institutional theory to explain differences in the level of new venture formation and development between the Confucian-based societies of East-Asia and Western countries such as the United States. We propose that the Confucian values underlying the institutional and cultural environments of East-Asian countries adversely affect the social legitimacy of entrepreneurial firms thereby inhibiting new venture formation and growth. The theoretical model and propositions developed in this paper extend the theoretical understanding of the interplay between Confucian values, cognitive behavior, and entrepreneurial firm legitimacy. Implications for international entrepreneurship research are discussed.
\end{abstract}

Keywords: Confucianism, Entrepreneurial Firm Legitimacy, International Entrepreneurship 
Scholars and policy makers around the world recognize the vital role small businesses and new ventures plays in a nation's economic progress. This entrepreneurial spirit and vigorous entrepreneurial activities often underlie a nation's economic vitality and provides innovative ideas for technological progress (Reynolds, 1987; Wright \& Marlow, 2012). U.S. labor statistics show that small businesses are major job creators, accounting for 80 percent of new jobs in the 1970s. In recent years, small businesses and entrepreneurial new ventures accounted for $62 \%$ of net new jobs (The U.S. Small Business Administration, Office of Advocacy, 2016). Entrepreneurial activities are particularly encouraged to stimulate the nation's economic growth in the less developed countries (Harper, 1991), and formerly planned economies (Chow \& Fung, 1996). Policy makers and entrepreneurship educators have acknowledged the importance of entrepreneurial activities in a growing economy and have made efforts to encourage programs intended to increase entrepreneurial activity and develop entrepreneurial institutional systems in the economy.

The levels of entrepreneurial orientation and support for these activities vary by country and region, largely influenced by the nation's formal and informal institutional contexts (McDougall \& Oviatt, 2000; Oviatt \& McDougal, 2005). For example, in comparing entrepreneurial activities in different nations, we found differences in the relative share of small businesses to large businesses across economic and cultural regions. Of particular interest are comparisons between the highly successful East-Asian economies and the United States where differences appear counterintuitive. For example, one would expect that the U.S., with its entrepreneurial culture and economic freedom, would have a higher percentage of small businesses than East-Asian countries, which are more conservative in terms of their socio-cultural institutional environment. Moreover, large conglomerates known as "keiretsu" in Japan and "Jae-Bol" in Korea have dominated the East-Asian economies for decades. Yet statistics for these economies show that small business are more prevalent in East-Asian countries than the United States. In terms of share of total employment, small businesses represented $90 \%$ in Korea, $85 \%$ in Japan, and $82 \%$ in China compared to only $53 \%$ in the United States (Note 1). These figures are in contrast to the general belief that entrepreneurial activity is greater in the United States. If true, why would there be a greater proportion of small businesses in East-Asian countries? One potential explanation is that failure and growth rates of entrepreneurial ventures between the two regions differ significantly.

At the institutional level, there are a number of broad social and economic factors affecting the success of new ventures in terms of its survival and growth (Allen, 2016; Reuber, Knight, Liesch, \& Zhou, 2018). These include cultural values and institutionalized perceptions of the legitimacy of entrepreneur-led new ventures (Covin \& Miller, 2014). In this paper, we consider the potential effect of the informal institutional environment, specifically the cognitive behavior of people in East-Asian region, on new venture legitimacy. East Asian countries such as Japan, Korea, and China are primarily Confucian-oriented in their cultural tradition, whereas the United States, as well as many other Western countries have a Protestant-Capitalism tradition and heritage (Weber, 1958; Yao, 2000). In this paper, we present a model based on institutional theory to explain how elements of Confucian philosophy affect the cognitive legitimacy of new ventures in East-Asian nations which in 
turn affect new venture formation and growth in the region. We develop propositions from this model and discuss implications for international entrepreneurship research.

\section{Social Legitimacy of Entrepreneurial Firms}

Factors affecting the growth of entrepreneurial firms are quite numerous and vary widely across social, economic, political, and institutional environments. For example, country-specific industry and market structures may affect discovery and the enactment of entrepreneurial opportunity (Oviatt \& McDougal, 2005). Governmental policies and programs regarding taxation, education, government procurement, and R\&D support can have varying effects on both large and small business activities. Country-specific profiles in institutional environment also include social knowledge and the values shared by societal members (Kostova, 1997). Differences between East-Asia and the West in small business development patterns might possibly be explained by differences in socio-cultural conditions such as Confucian-oriented culture.

Institutional theorists have proposed that organizations can increase their survival prospects by obtaining the legitimacy or social support from external constituents in its institutional environment (Powell, 1988). Organizations are therefore motivated to pursue social norms, institutional values, and procedural standards in their environment to obtain legitimacy from their stakeholders. Adherence to institutional prescriptions enhances the ease of access to key resources (Garud, Schildt, \& Lant, 2014; Pfeffer \& Salancik, 1978). Singh, Tucker, and House (1986) found that external legitimacy is more prominently related to the organization's mortality than its internal coordination processes. In empirical studies, for example, of child care organizations, institutional linkages with government, community constituents, and legislative and administrative authorities increased an organization's survival rate (Baum \& Oliver, 1991).

Although the concept of social legitimacy applies equally to large and small organizations, organizational legitimacy issues are more critical to smaller and younger organizations (Navis \& Glynn, 2011). The "liability of newness" argument (Stinchcombe, 1965) emphasizes the higher rate of failure in new organizations due to lack of social endorsement, organizational stability, and sufficient resources. A new organization's main sources of liability are the lack of organizational stability and social legitimacy or endorsements from its key stakeholders such as customers, capital providers, and potential partners. New organizations need time to establish stable links with important external constituents, which render new organizations susceptible to environmental selection processes in ecological environments (Hannan \& Freeman, 1984).

Population ecologists add that environmental selection pressures are proposed to favor structurally inert or stable organizations because those reliable and accountable organizations are more attractive to customers and external institutions (Hannan \& Freeman, 1984). Empirical research revealed that external legitimacy decreases the liability of newness (Singh et al, 1986), and mortality rates tend to decline with increased organizational age (Freeman, Carroll \& Hannan, 1983). Stinchcombe (1965) argued that institutional attachment can lower the risks of new organizations because attachments with established institutions can 
compensate for the legitimacy, stability, and resources new organizations usually lack. A recent study, for example, showed that the regional social legitimacy of entrepreneurship affected entrepreneurial intentions and start-up behaviors (Kibler, Kautonen, \& Fink, 2014). In addition, gaining legitimacy increases access to financial resources such as crowdfunding (Bock, Kinder, \& Koeck, 2014; Diez-Martin, Blanco-Gonzalez, \& Prado-Rioman, 2016). Empirical research examining new franchisers' survival rates suggest that franchisers who achieved external firm legitimacy survived longer and were more successful in their franchising (Shane \& Foo, 1999).

Organization theorists also allude to the "liability of smallness," which suggests that organizational mortality rates tend to decline with increased size (Singh et al, 1986). This is because larger organizations are better able to obtain critical resources from its political and legislative environments (Baum \& Oliver, 1991; Karen \& Middleton, 2013). Empirical studies also support that organizational mortality rates tend to be negatively related with age (Carroll \& Delacroix, 1982). As organizations mature, they are more likely to develop institutional-level relationships with other organizations and receive endorsements from powerful collective actors. These institutional linkages have a greater impact in reducing the mortality rate of small organizations than those of large organizations (Wright \& Marlow, 2012). Barringer and Harrison (2000) argued that small firms can increase their reputation, image, and prestige through partnerships with larger, better-established companies.

Legitimization problems are more critical to small and new entrepreneurial firms because they lack performance history, prestige, and an established image. Anecdotal evidence supports this notion of social legitimacy. Successes in high-tech ventures such as Netflix, Sun Micro Systems, YouTube, and Amazon dramatically increased the social legitimacy of similar high-tech and e-commerce ventures (e.g., Uber). This "inflated" legitimacy likely positively impacted the motivation potential entrepreneurs and investors had to enter into other high-tech, high-risk ventures. Obtaining or losing this legitimacy can be a strong determinant for an entrepreneurial firm's survival and prosperity, which is especially critical to new and high-risk ventures.

\section{Confucian Values and Entrepreneurial Firm Legitimacy}

Different societies possess different cultural orientations and cognitive styles (Abramson, Keating, \& Lane, 1996), which is affected by elements in the society, such as history, traditions, and institutional systems. Culture, defined as "the collective programming of the mind which distinguishes the members of one human group from another", shapes the member's patterns of values, ideas, and systems of value (Hofstede, 1980: 25). Culture is a nation's endogenous environment and not prone to change (Hofstede, 1993) and has a particular role in influencing societal members' value systems, further affecting the development of social institutions.

In entrepreneurship research, there has been a long-standing issue concerning the influence of culture on entrepreneurship (Allen, 2016; Covin \& Miller, 2014; George \& Zahra, 2002). Many researchers have empirically examined such cultural effects on entrepreneurial activities, such as innovativeness, risk-taking behavior, and entrepreneurial enactment (e.g., 


\section{Macrothink}

Journal of Management Research

ISSN 1941-899X

2019, Vol. 11, No. 2

Busenitz \& Lau, 1996; Karen \& Middleton, 2013; Kibler, Kautonen, \& Fink, 2014; Mueller \& Thomas, 2000;). For example, Shane (1992) found that national values of individualism and lack of power distance are positively related to higher rates of innovations in the nation. Mueller and Thomas (2000) investigated the relationship between national culture and internal locus of control of entrepreneurs and found that an internal locus of control orientation is more prevalent in individualistic cultures than in collectivistic cultures.

Individual cognitive style (Messick, 1984) is determined in large part by the cultural environment of the society (Abramson et al., 1996; Allinson \& Hayes, 1996). Members of one culture have different cognitive and perceptive styles compared to their counterparts in a different culture. Social legitimacy is a culture-specific process affected by societal members' cognitive and perceptive orientations. While social legitimacy may be a universal concept, the processes that lead to legitimacy are culture-specific. Thus, it is possible for the legitimacy of a firm to be perceived and assessed more harshly in some cultures thus adversely affecting entrepreneurial firm development in those cultures.

Within an institutional theory framework, we propose that Confucian values and traditions have a negative effect on a new entrepreneurial firm's legitimacy. As a result, the availability of resources needed for the exploitation of entrepreneurial opportunity, survival, and growth is more limited in societies dominated by Confucian values. Figure 1 is a depiction of our model showing the effect of Confucian values on venture legitimacy. In our proposed model, we incorporate Hofstede's (1980) cultural dimensions, such as power distance, collectivism-individualism, and uncertainty avoidance; these have been extremely well-documented in cross-cultural studies including international entrepreneurship research. The model and propositions developed in this paper depict how the Confucian values are related to those cultural dimensions and further the cognitive legitimacy of new ventures in the society. 


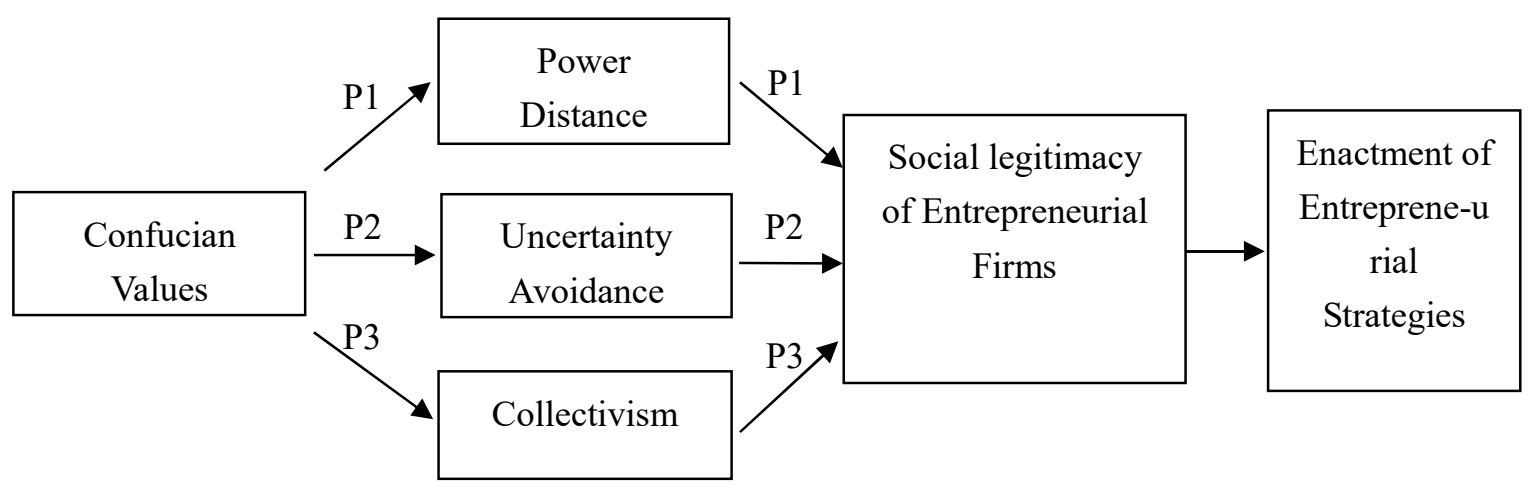

Figure 1. Effect of Confucian Values on New Venture Legitimacy and Enactment of Entrepreneurial Strategies

Today's East-Asian nations can trace their cultural roots to Confucianism, founded by K'ung-Fu-Tzu (551-479 BC). Confucian philosophy has had a profound influence on the cultural traditions of East-Asian nations, principally China, Japan, and Korea (Yao, 2000). It has become a part of these nations' value systems, which distinctively differentiate them from the cultures of Western societies. It has its roots on the teachings and philosophy of Confucius, who established guidelines for relationships with others. Confucian virtues place special emphasis on the stability of society, consensus, social harmony, loyalty, duty, patience, and moderation ( $\mathrm{Tu}, 1998)$.

Confucian societies are based on close-knit family structures and hierarchical relationships encouraging people to respect authority and seniority. Confucian virtues urge societal members to restrain or subsume their self-interest for the benefit of the group and social harmony (Yao, 2000). Social ties and group cohesiveness are highly emphasized. Hofstede and Bond (1998: 16) identified "Confucian dynamism" as the relative importance of persistence; ordering relationships by status and observing the order; thrift; and by having a sense of shame. Confucian heritage also affects attitudes and behavior in the workplace. Ornatowski (1996), for example, argued that Confucian values underlie the adoption of specific managerial practices such as lifetime employment and seniority-based wages. International scholars also relate Confucian values with the rapid economic development of East-Asian nations such as Japan, Korea, and Taiwan (e.g., Hofstede \& Bond, 1988; Rozman, 1992; Yeung \& Tung, 1996).

East-Asian countries appear to have lower rates of "opportunistic-type" entrepreneurial activities (Reynolds et al., 2001). This may be due in large part to Confucian cultural orientations where behavior inconsistent with established norms are discouraged and deviations from group expectations are socially and culturally punished. Confucian philosophy emphasizes group unity, consensus, and social harmony (Shane, 1993) and such a cultural orientation can have a negative influence on the entrepreneurial business innovations and enactment of entrepreneurial strategies. That is, within an institutional framework, East-Asian innovating entrepreneurs are perceived as deviating from group expectations and unity, which, in turn, negatively affects the social legitimacy of new ventures further making 
it difficult for them to obtain necessary resources for founding and growing entrepreneurial firms.

In Confucian cultures, there is a tendency for power to be distributed unequally. Power distance has been defined as "the extent to which the less powerful members of organizations and institutions accept and expect that power is distributed unequally" (Hofstede \& Bond, 1988: 10). Hofstede (1980) noted that high power-distance societies have a hierarchical social structure where power, wealth, and prestige are used to reinforce social inequality. In high power-distance cultures, control systems are more elaborate, and people are unwilling to accept changes in social mobility (Hofstede, 1980).

Proposition 1. Confucian values increase power distance in cognitive perception, which in turn, negatively affects the social legitimacy of new ventures in the society.

Confucian traditions that emphasize order in relationships, respect for authority, social stability, patience, and moderation often influences a society to be more conservative. Uncertainty-avoidance refers the extent to which "...a culture programs its members to feel either uncomfortable or comfortable in unstructured situations" (Hofstede \& Bond, 1988: 11). Hofstede (1980) noted that cultures high on this are inherently more anxious about unpredictability and ambiguity, and change is even perceived as dangerous. In high uncertainty avoidance cultures such as China, Japan, and Korea, people are less willing to take risks than their counterparts in lower uncertainty avoidance cultures. As a result, people in Confucian societies are less likely to expect or accept changes in social structures. Such a cultural orientation has a negative effect on the legitimacy of new ventures that are perceived as a 'change agent' by the societal members. New ventures in these societies are likely to be perceived as disruptive to the existing power structure and will have more difficulty in obtaining resources needed for growth.

Proposition 2. Confucian values increase uncertainty avoidance in cognitive perception, which in turn, negatively affects the social legitimacy of new ventures in the society.

A society's uncertainty avoidance also has important implications on the level of a nation's opportunistic entrepreneurial activity. Mueller and Thomas (2000) argued that cultures high in uncertainty avoidance negatively influence entrepreneurial behavior. A culture's emphasis on Confucianism and its inherent desire for the stability of society and conservatism arguably strengthens the cultural tendency of collectivism in the society. As a result, young entrepreneurial firms will have greater difficulty in obtaining resources needed for growth and survival in such societies.

Proposition 3. Confucian values increase collectivism in cognitive perception, which in turn, negatively affects the social legitimacy of new ventures in the society.

\section{Discussion}

In comparative entrepreneurship research, cross-cultural studies have generally looked at the impact of cultural differences on entrepreneurial orientations such as innovativeness, proactiveness, and risk-taking behavior (Jones et al., 2011; Oviatt \& McDougal, 2005), but 
rarely focusing on the impact of cultural attributes on the cognitive legitimacy of entrepreneurial firms. Little research have investigated Confucian values dominant in EastAsian countries and its impact on the perceptual legitimacy of entrepreneurial activities (e.g., enactment of entrepreneurial opportunity). Cultural attribute is a crucial component of a nation's institutional environment that fosters or hinders entrepreneurial intensity (Hayton, George, \& Zahra, 2002; Wach 2015). In this regard, understanding the legitimization process in cross-cultural contexts helps explain the varying degrees of small and new venture development across countries and cultures. More specifically, the model and propositions developed in the paper enhances our understanding of the interplay between Confucian values, cognitive behavior of societal members, and cognitive legitimacy of entrepreneurial firms in the region.

We have proposed that Confucian values would negatively impact East-Asian new entrepreneurial ventures in obtaining external legitimacy, which plays an important role in obtaining the necessary resources for new ventures' founding and growth. Confucian-oriented East-Asian cultures therefore tend to constrain the ability of new ventures to obtain social legitimacy, which is a vital factor for a venture's growth and transition into a more established firm. In this paper, we provide a framework for entrepreneurship researchers to help better understand how a nation's cultural and institutional environment, specifically Confucian values, impact the cognitive behavior of firm legitimacy which further affects the entrepreneurial orientation and enactment of entrepreneurial strategies.

Our framework also helps entrepreneurship researchers, including policy makers, better assess the cultural values in relation to a nation's cultural and institutional entrepreneurial environment. Entrepreneurial intensity and prosperity lag in many countries despite efforts to grow the entrepreneurial business sector through diverse supportive programs and policies. Since cultural values as behavioral traits can affect entrepreneurial firm legitimacy - a critical social resource for entrepreneurial firm survival and growth - policy makers also need to devise strategies and programs in formal and informal institutional environments to counteract the negative impact of such cultural orientations to encourage entrepreneurial prosperity. Cultural change cannot be achieved in the short term, rather it requires taking a long-term perspective. However, perceptual changes in new venture legitimacy may be the first step in the process of stimulating a nation's economic vitality within the entrepreneurial sector. Future researchers should also look more closely at the cultural changes in the region and its impact on managerial practices including entrepreneurial strategies and enactment activities.

The model and propositions developed in this paper will of course require empirical testing. We believe that the theoretical model we presented in this paper extends our understanding about the role of cultural orientation, specifically Confucian values, on cognitive legitimacy of entrepreneurial firms. In conclusion, we suggest that the clearer identification of the role of Confucian values on individual cognitive behavior and managerial actions will contribute to a better understanding of organizational and entrepreneurial phenomena in East Asian countries. 


\section{Ml Macrothink}

Journal of Management Research

ISSN 1941-899X

2019, Vol. 11, No. 2

\section{Notes}

Note 1. The criterion used to define small business for these countries was firms with fewer than 300 employees. If the criterion used were the same for the United States, then the proportion of small businesses would be even greater. Source: Korea: Statistics in Small and Medium Business, Korea Small and Medium Business Administration (SMBA, 2006), www.smba.go.kr; Japan: 2017 White Paper on Small and Medium Enterprises in Japan, Small and Medium Enterprise Corporation (JASMEC); China: Lim, H. (ed.), SME in Asia and Globalization, ERIA Research Project, National Bureau of Statistics of China, 2008.

\section{References}

Abramson, N.R., Keating, R.J., \& Lane, H.W. (1996). Cross-national cognitive process differences: A comparison of Canadian, American and Japanese managers. Management International Review, 36(2). 123-147.

Allen, I. (2016). International entrepreneurship theory: Past, present and way forward. Entrepreneurial Business and Economics Review, 4(4), 93-103.

Allinson, C.W., \& Hayes, J. (1996). Cross-national differences in cognitive Style: Implications for management. International Journal of Human Resource Management, 11(1), 161-170. https://doi.org/10.1080/095851900340042.

Barringer, B.R., \& Harrison, J.S. (2000) Walking a tightrope: Creating value through interorganizational relationships. Journal of Management, 26(3), 367-403. https://doi.org/10.1177/014920630002600302.

Baum, J.A.C., \& Oliver, C. (1991). Institutional linkages and organizational mortality. Administrative Science Quarterly, 36(2), 187-218. https://doi.org/10.2307/2393353.

Busenitz, L.W., \& Lau, C.M. (1996). A cross-cultural cognitive model of new venture creation. Entrepreneurship Theory and Practice, 20(4), 25-39. https://doi.org/10.1177/104225879602000403.

Carroll, G.R., \& Delacroix, J. (1982). Organizational mortality in the newspaper industries Argentina and Ireland: An ecological approach. Administrative Science Quarterly, 27(2), 169-198. https://doi.org/10.2307/2392299.

Chow, C.K.W., \& Fung, M.K.Y. (1996). Firm dynamics and industrialization in the Chinese economy in transition: Implications for small business policy. Journal of Business Venturing, 11, 489-505. https://doi.org/10.1016/S0883-9026(96)00019-5

Covin, J.G., \& Miller, D. (2014). International entrepreneurial orientation: Conceptual considerations, research themes, measurement issues, and future research directions. Entrepreneurship: Theory \& Practice, 38(1), 11-44. https://doi.org/10.1111/etap.12027.

Diez-Martin F., Blanco-Gonzalez, A., \& Prado-Rioman, C. (2016). Explaining nation-wide differences in entrepreneurial activity: a legitimacy perspective. International 


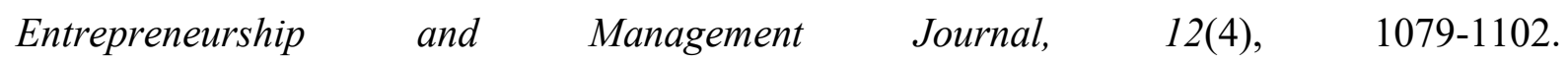
https://doi.org/10.1007/s11365-015-0381-4.

Freeman, J., Carroll, G.R., \& Hannan, M.T. (1983). The liability of newness: Age dependence in organizational death rates. American Sociological Review, 48(5), 692-710. https://doi.org/10.2307/2094928.

Frydrych, D., Bock, A.J., Kinder, T., \& Koeck, B. (2014). Exploring entrepreneurial legitimacy in reward-based crowdfunding. International Journal of Entrepreneurial Finance, 16(3), 247-269. https://doi.org/10.1080/13691066.2014.916512.

Garud, R., Schildt, H.A., \& Lant, T.K. (2014). Entrepreneurial storytelling, future expectations, and the paradox of legitimacy. Organization Science, 25(5), 1479-1492. https://doi.org/10.1287/orsc.2014.0915.

George, G., \& Zahra, S.A. (2002). Culture and its consequences for entrepreneurship. Entrepreneuship Theory and Practice, 26(4), 5-8. https://doi.org/10.1177/104225870202600401.

Hannan, M.T., \& Freeman, J.H. (1984). Structural inertia and organizational change. American Sociological Review, 49(2), 149-164. https://doi.org/10.2307/2095567.

Harper, M. (1991). Enterprise development in poorer nations. Entrepreneurship Theory and Practice, 15(4), 7-11. https://doi.org/10.1177/104225879101500404.

Hayton, J.C., George, G., \& Zahra, S.A. (2002). National culture and entrepreneurship: A review of behavioral research. Entrepreneurship: Theory \& Practice, 26(4), 33-52. https://doi.org/10.1177/104225870202600403.

Hofstede, G. (1980). Culture's consequences: International differences in work-related values. Sage, Beverly Hills, CA.

Hofstede, G. (1993). Cultural constraints in management theories. Academy of Management Executive, 7(1), 81-94. https://doi.org/10.5465/AME.1993.9409142061.

Hofstede, G., \& Bond, M. (1988). The Confucian connection: From cultural roots to economic growth. Organizational $\quad$ Dynamics, $16(4), \quad 4-21$. https://doi.org/10.1016/0090-2616(88)90009-5

Jones, M.V., Coviello, N., \& Tang, Y.K. (2011). International entrepreneurship research (1989-2009): A domain ontology and thematic analysis. Journal of Business Venturing, 26(6), 632-659. https://doi.org/10.1016/j.jbusvent.2011.04.001.

Kibler, E., Kautonen, T., \& Fink, M. (2014). Regional social legitimacy of entrepreneurship: implications for entrepreneurial intention and start-up behavior. Regional Studies, 48(6), 995-1015. https://doi.org/10.1080/00343404.2013.851373.

Kostova, T. (1997). Country institutional profiles: Concept and measurement. Academy of Management Best paper proceedings, 180-184. https://doi.org/10.5465/AMBPP.1997.4981338. 
McDougall, P.P., \& Oviatt, B.M. (2000). International entrepreneurship: The intersection of two research paths. Academy of Management Journal, 43(5), 902-906. https://doi.org/10.5465/1556418.

Messick, S. (1984). The nature of cognitive styles: Problems and promise in educational $\begin{array}{llll}\text { practice. } & \text { Educational } & \text { Psychologist, } & \text { 19(2), }\end{array}$ https://doi.org/10.1080/00461528409529283.

Middleton, K.L.W. (2013). Becoming entrepreneurial: gaining legitimacy in the nascent phase. International Journal of Entrepreneurial Behavior \& Research, 19(4), 404-424. https://doi.org/10.1108/IJEBR-04-2012-0049

Mueller, S.L., \& Thomas, A.S. (2000). Culture and entrepreneurial potential: A nine country study of locus of control and innovativeness. Journal of Business Venturing, 16(1), 51-75. https://doi.org/10.1016/S0883-9026(99)00039-7.

Navis, C., \& Glynn, M.A. (2011). Legitimate distinctiveness and the entrepreneurial identity: Influence on investor judgments of new venture plausibility. Academy of Management Review, 36(3), 479-499. https://doi.org/10.5465/amr.2008.0361.

Ornatowski, G.K. (1996). Confucian ethics and economic development: A study.... Journal of Socio-Economics, 25(5), 571-590. https://doi.org/10.1016/S1053-5357(96)90018-9.

Oviatt, B.M., \& McDougall, P.P. (2005). Defining international entrepreneurship and modeling the speed of internationalization. Entrepreneurship: Theory \& Practice, 29(5), 537-554. https://doi.org/10.1111/j.1540-6520.2005.00097.x.

Pfeffer, J., \& Salancik, G.R. (1978). The external control organizations. Harper and Row, NY.

Powell, W.W. (1988). Institutional effects on organizational structure and performance. In Lynne Zucker, ed, Institutional patterns and organizations: Culture and environment. 115-136, Cambridge, MA.

Reynolds, P.D. (1987). New firms: Societal contribution versus survival potential. Journal of Business Venturing, 2(3), 231-246. https://doi.org/10.1016/0883-9026(87)90011-5.

Reynolds, P., Camp, S., Bygrave, W., Autio, E., \& Hay, M. (2001). Global Entrepreneurship Monitor $2001 \quad$ Executive Report. http://www.gemconsortium.org/download/1030396133156/GEMGlobal2001 report.

Reuber, A.R., Knight, G.A., Liesch, P.W., \& Zhou, L. (2018). International entrepreneurship: The pursuit of entrepreneurial opportunities across national borders. Journal of international Business Studies, 49(4), 395-406. https://doi.org/10.1057/s41267-018-0149-5.

Rozman, G. (1992). The Confucian faces of capitalism. In M. Borthwick, Ed, Pacific Century, Boulder, Westview Press.

Shane, S. A. (1992). Why Do Some societies invent more than others? Journal of Business Venturing, 7(1), 29-46. https://doi.org/10.1016/0883-9026(92)90033-N. 
Shane, S. (1993). Cultural influences on national rates of innovation. Journal of Business Venturing, 8(1), 59-73. https://doi.org/10.1016/0883-9026(93)90011-S.

Shane, S., \& Foo, M. (1999). New firm survival: Institutional explanations for new franchisor mortality. Management Science, 45(2), 142-160. https://doi.org/10.1287/mnsc.45.2.142.

Singh, J.V., Tucker, D.J., \& House, R.J. (1986). Organizational legitimacy and the liability of newness. Administrative Science Quarterly, 31(2), 171-193. https://doi.org/10.2307/2392787.

Stinchcombe, A.L. (1965). Organizations and social structures. In James G. March, ed, Handbook of Organizations, 142-193. Rand McNally, Chicago.

Tu, W. (1998). Joining east and west. Harvard International Review, 20(3), 44-49. ISSN 0739-1854.

Yao, X. (2000). An introduction to Confucianism. Cambridge University Press, NY.

Yeung, I.YM., \& Tung, R.L. (1996). Achieving business success in Confucian societies: The importance of GuanXi (Connections). Organizational Dynamics, 25(2), 54- 65. https://doi.org/10.1016/S0090-2616(96)90025-X.

Wach, K. (2015). Entrepreneurial orientation and business internationalization process: The theoretical foundations of international entrepreneurship. Entrepreneurial Business and Economics Review, 3(2), 9-24. https://doi.org/10.15678/EBER.2015.030202.

Weber, M. (1958). The Protestant ethic and the spirit of capitalism. Scribner, NY.

Wright, M., \& Marlow, S. (2012). Entrepreneurial activity in the venture creation and development process. International Small Business Journal: Researching Entrepreneurship, 30(2), 107-114. https://doi.org/10.1177/0266242611432793. 